\title{
Author Correction: One-plasmid double-expression His-tag system for rapid production and easy purification of MS2 phage-like particles
}

\author{
Pavel Mikel ${ }^{1,2}$, Petra Vasickova ${ }^{1} \&$ Petr Kralik $\mathbb{D}^{1}$
}

Correction to: Scientific Reports https://doi.org/10.1038/s41598-017-17951-5, published online 13 December 2017

In the original version of the Supplementary File which accompanied this Article, the plasmid sequence was provided as a flat image. The file has now been replaced: the corrected version contains the full sequence of the plasmid used in this study in a machine readable format.

(c) Open Access This article is licensed under a Creative Commons Attribution 4.0 International License, which permits use, sharing, adaptation, distribution and reproduction in any medium or format, as long as you give appropriate credit to the original author(s) and the source, provide a link to the Creative Commons license, and indicate if changes were made. The images or other third party material in this article are included in the article's Creative Commons license, unless indicated otherwise in a credit line to the material. If material is not included in the article's Creative Commons license and your intended use is not permitted by statutory regulation or exceeds the permitted use, you will need to obtain permission directly from the copyright holder. To view a copy of this license, visit http://creativecommons.org/licenses/by/4.0/.

(c) The Author(s) 2019

${ }^{1}$ Veterinary Research Institute, Hudcova 296/70, 621 00, Brno, Czech Republic. ${ }^{2}$ Department of Experimental Biology, Faculty of Science, Masaryk University, Kamenice 753/5, 625 00, Brno, Czech Republic. Correspondence and requests for materials should be addressed to P.M. (email: mikel@vri.cz) 